\title{
Effect of Organic Manures and Biofertilizers on Quality of Spinach Beet (Beta vulgaris var. bengalensis)
}

\author{
Asma Jabeen*, Sumati Narayan, Khursheed Hussain, \\ Shakeel Ahmed Mir and Farooq Ahmed Khan
}

Division of Vegetable Science, Sher-e-Kashmir University of Agricultural Sciences and Technology of Kashmir, Shalimar-190025, J\&K, India

*Corresponding author

\section{A B S T R A C T}

A field experiment was conducted at Vegetable Experimental Field, SKUAST- K Shalimar during Rabi season 2016-17 to evaluate the effect of organic manures and biofertilizers on

\section{Keywords}

Spinach beet,

Vermicompost,

Biofertilizers,

Quality

\section{Article Info}

Accepted:

10 August 2018

Available Online:

10 September 2018 quality of spinach beet. The experiment was laid out in RCBD with nine treatment combinations replicated three times. The treatments comprised of organic manures viz., farm yard manure, sheep manure, vermicompost, mustard cake and two types of biofertilizers namely Azospirillum and PSB including RFD (recommended fertilizer dose) as control. Results revealed that quality parameters like dry matter content $(15.92,16.47$ and 29.26), ascorbic acid content $\left(202.52,166.10\right.$ and $\left.155.12 \mathrm{mg} 100 \mathrm{~g}^{-1}\right)$, crude fibre content (9.50, 8.86 and $7.76 \%)$ and leaf chlorophyll content $\left(3.25,0.98\right.$ and $\left.0.76 \mathrm{mg} \mathrm{g}^{-1}\right)$ were highest with the treatment $\mathrm{T}_{6}$ (vermicompost @ 3 tonnes ha ${ }^{-1}+$ biofertilizers @ $5 \mathrm{~kg} \mathrm{ha}^{-1}$ ). Lowest nitrate content $\left(447.33,348.33\right.$ and $\left.268.33 \mathrm{mg} \mathrm{kg}^{-1}\right)$ in leaves were found with the treatment $\mathrm{T}_{7}$ (FYM @ $12.0 \mathrm{t} \mathrm{ha}^{-1}+$ biofertilizers@ $5 \mathrm{~kg} \mathrm{ha}^{-1}$ ) and was statistically at par (453.00, 355.39 and $270.33 \mathrm{mg} \mathrm{kg}^{-1}$ ) with treatment $\mathrm{T}_{6}$ (vermicompost @ 3 tonnes ha ${ }^{-1}+$ biofertilizers@ $\left.5 \mathrm{~kg} \mathrm{ha}^{-1}\right)$. Highest leaf moisture content $(91.97,90.23$ and $87.57 \%$ ) was registered where mustard cake@1.2 $\mathrm{t} \mathrm{ha}^{-1}$ was applied.The highest benefit cost ratio (B:C) of spinach beet (3.84) was also obtained with the application of vermicompost @ 3 tonnes ha ${ }^{-1}+$ biofertilizers @ $5 \mathrm{~kg} \mathrm{ha}^{-1}$.

\section{Introduction}

Spinach beet (Beta vulgaris var. bengalensis; $2 \mathrm{n}=2 \mathrm{x}=18$ ), commonly known as 'Indian spinach' in English and 'Palak' in Hindi, originated from Indo-Chinese region (Nath, 1976) belongs to the genus Beta, specie vulgaris and family Chenopodiaceae. Leaves of this might have been first used in Bengal and hence known as var. bengalensis. It is also called as Beet leaf and Desi palak. It is closely related to beet root, sugar beet, and Swiss chard. Sea beet (Beta vulgaris var. maritima) is the ancestor of palak. It is commonly grown for its tender and soft succulent leaves.

Spinach beet leaves are valued much for their medicinal properties. It is a good source of natural antioxidants such as flavonoids, polyphenols, vitamins and folic acid. Organic manures like vermicompost contains water soluble components such as humic acid, 
growth regulators, vitamins and micronutrients which increase the availability of nutrients resulting in better quality produce.

Excessive use of inorganic fertilizers creates environment related problems and situation can be improved through the use of biofertilizer (Saadatnia and Riahi, 2009). Organic manures have the potential to mitigate the soil degradation and gave higher benefit cost ratio. In view of the above facts the research was conducted with the following objective:

To assess the effect of organic manures and biofertilizers on quality of spinach beet and to work out the economics.

\section{Materials and Methods}

The present study was carried out during Rabi season of 2016-17 at Vegetable Experimental Field of Division of Vegetable Science, SKUAST-Kashmir, using one variety of spinach beet "Pusa Jyoti" with a spacing of 30 $\mathrm{cm}$ apart in rows and later thinned to $10 \mathrm{~cm}$ spacing between plants within a row experimented in Randomized Complete Block Design with three replications. The treatment details are as below:

$\mathrm{T}_{1}=$ Recommended dose of fertilizer (RDF) i.e. $\mathrm{N} @ 60.0 \mathrm{~kg} \mathrm{ha}^{-1}$

$\mathrm{T}_{2}=$ Vermicompost @ $3.0 \mathrm{tha}^{-1}$

$\mathrm{T}_{3}=$ Farmyard manure@ $12.0 \mathrm{tha}^{-1}$

$\mathrm{T}_{4}=$ Sheep manure @ $10.0 \mathrm{t} \mathrm{ha}^{-1}$

$\mathrm{T}_{5}=$ Mustard cake @ $1.2 \mathrm{tha}^{-1}$

$\mathrm{T}_{6}=\mathrm{T}_{2}+$ Biofertilizers (Azospirillum + PSB @ $5.0 \mathrm{~kg} \mathrm{ha}^{-1}$ )

$\mathrm{T}_{7}=\mathrm{T}_{3}+$ Biofertilizers (Azospirillum + PSB @ $5.0 \mathrm{~kg} \mathrm{ha}^{-1}$ )
$\mathrm{T}_{8}=\mathrm{T}_{4}+$ Biofertilizers (Azospirillum + PSB @ $5.0 \mathrm{~kg} \mathrm{ha}^{-1}$ )

$\mathrm{T}_{9}=\mathrm{T}_{5}+$ Biofertilizers (Azospirillum + PSB @ $5.0 \mathrm{~kg} \mathrm{ha}^{-1}$ )

The quality observations were recorded on moisture content, dry matter content, crude fibre content, leaf chlorophyll content, leaf ascorbic acid content and leaf nitrate content. To find out the BCR the following formula was used:

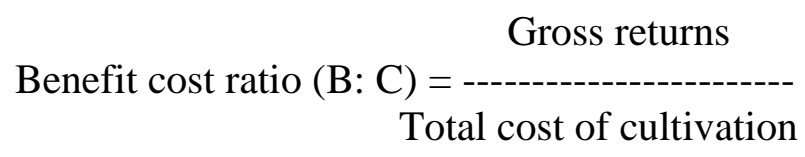

Quality attributes were recorded at first, second and third cuttings respectively. Data was analyzed as per standard statistical procedures (Gomez and Gomez, 1984).

\section{Results and Discussion}

The findings of the present study as well as relevant discussion are summarized under following headings:

\section{Leaf moisture content}

Data presented in table 1 revealed that highest moisture content $(91.97,90.23$ and $87.57 \%$ ) was recorded in treatment $\mathrm{T}_{5}$ (Mustard cake @ $1.2 \mathrm{t} \mathrm{ha}^{-1}$ ) followed by $(89.15,88.57$ and $86.73 \%$ ) treatment $\mathrm{T}_{3}$ (Farmyard manure@ $12.0 \mathrm{t} \mathrm{ha}^{-1}$ ) whereas lowest moisture content $(84.08,83.53$ and $81.73 \%)$ was recorded with the treatment $\mathrm{T}_{6}$ (Vermicompost@3.0 t ha ${ }^{-1}+$ Biofertilizers@5.0 $\mathrm{kg} \mathrm{ha}^{-1}$ ). The above result is in conformity with Bharad et al., (2013).

Regarding cutting effect on leaf moisture, maximum leaf moisture was recorded in first cutting $\left(\mathrm{C}_{1}\right)$, followed by second cutting $\left(\mathrm{C}_{2}\right)$ whereas minimum leaf moisture content was recorded in third cutting $\left(\mathrm{C}_{3}\right)$. The moisture 
content was maximum in $\mathrm{C}_{1}$ because moisture content is directly related to leaf area as cutting increases the leaf area and thus moisture content decreases.

\section{Dry matter content}

Table 1 depicts that the maximum value for dry matter (15.92, 16.47 and $18.27 \%$ ) was recorded in treatment $\mathrm{T}_{6}$ (Vermicompost@3.0 $\mathrm{t} \mathrm{ha}^{-1}+$ Biofertilizers @ $5.0 \mathrm{~kg} \mathrm{ha}^{-1}$ ) followed by $(14.25,16.33$ and $17.73 \%)$ treatment $\mathrm{T}_{2}$ (Vermicompost@3.0 t ha ${ }^{-1}$ ). Minimum dry matter $(8.03,9.77$ and $12.43 \%)$ was registered in treatment $\mathrm{T}_{5}$ (Mustard cake @ $1.2 \mathrm{t} \mathrm{ha}^{-1}$ ). The improvement in dry matter may be because of better availability and uptake of nitrogen which might have led to balanced $\mathrm{C} / \mathrm{N}$ ratio and increased activity of plant metabolism. The above result is in conformity with that of Mehta et al., (2012) and Joshi and Pal (2010).

With increase in leaf area, dry matter also increases and in response to cutting maximum dry matter was recorded in $\mathrm{C}_{3}$ and minimum was recorded in $\mathrm{C}_{1}$.

\section{Crude fibre content}

Table 1 showed that maximum fibre content (9.50, 8.86 and $7.76 \%)$ was observed in treatment $\quad \mathrm{T}_{6} \quad$ (Vermicompost@3.0 $\quad \mathrm{t} \mathrm{ha}^{-1}+$ Biofertilizers @ $5.0 \mathrm{~kg} \mathrm{ha}{ }^{-1}$ ) which was statistically at par(9.35, 8.68 and 7.45) and $(9.10,8.56$ and $7.36 \%)$ with the treatments $\mathrm{T}_{8}$ (Sheep manure@10.0 t ha ${ }^{-1}+$ Biofertilizers @ $5.0 \mathrm{~kg} \mathrm{ha}^{-1}$ ) and $\mathrm{T}_{7}$ (Farmyard manure @ $12.0 \mathrm{t} \mathrm{ha}^{-1}+$ Biofertilizers @ $5.0 \mathrm{~kg} \mathrm{ha}^{-1}$ ). Minimum fibre content $(7.59,6.55$ and 6.25 $\%$ ) was recorded in treatment $\mathrm{T}_{3}$ (Farmyard manure @ $12.0 \mathrm{t} \mathrm{ha}^{-1}$ ) and was at par (7.97, 7.02 and $6.02 \%$ ) with treatment $\mathrm{T}_{5}$ (Mustard cake@1.2 $\left.\mathrm{t} \mathrm{ha}^{-1}\right)$. Maximum fibre content in palak was reported with the application of poultry manure (Dange et al., 2013).
As regards to cutting, maximum crude fibre content was recorded in $\mathrm{C}_{1}$ followed by $\mathrm{C}_{2}$ and minimum was recorded in $\mathrm{C}_{3}$.

\section{Leaf chlorophyll}

Table 1 revealed that maximum leaf chlorophyll content $(3.25,0.93$ and $0.76 \mathrm{mg}$ $\mathrm{g}^{-1}$ ) in spinach beet was recorded with the treatment $\mathrm{T}_{6}$ (Vermicompost@3.0 $\mathrm{t} \mathrm{ha}^{-1}+$ Biofertilizers @ $5.0 \mathrm{~kg} \mathrm{ha}^{-1}$ ) followed by (2.96, 0.86 and $0.73 \mathrm{mg} \mathrm{g}^{-1}$ ) treatment $\mathrm{T}_{2}$ (Vermicompost @ $3.0 \mathrm{t} \mathrm{ha}^{-1}$ ) whereas minimum leaf chlorophyll (1.08, 0.28 and 0.21 $\mathrm{mg} \mathrm{g}^{-1}$ ) was recorded in the treatment $\mathrm{T}_{1}$ (RFD). Similar results of improvement in chlorophyll content due to addition of organic manures have also been found by Singh et al., (2014) and Narkhede et al., (2011). More chlorophyll content in leaves might be due to macro and micro nutrients supplied by vermicompost and biofertilizers particularly nitrogen which is an important constituent of chlorophyll. As regards to cutting, maximum chlorophyll content was registered in first cutting $\left(\mathrm{C}_{1}\right)$ followed by $\mathrm{C}_{2}$ whereas minimum chlorophyll content was recorded in $\mathrm{C}_{3}$. The above result is in conformity with that of Gairola et al., (2009).

\section{Ascorbic acid content:}

The maximum ascorbic acid content(202.52, 166.10 and $155.12 \mathrm{mg} 100 \mathrm{~g}^{-1}$ ) was recorded in treatment $\mathrm{T}_{6}$ (Vermicompost@3.0 t ha ${ }^{-1}+$ Biofertilizers @ $5.0 \mathrm{~kg} \mathrm{ha}^{-1}$ ) followed by (197.06, 99.02 and 85.24 mg $100 \mathrm{~g}^{-1}$ ) treatment $\mathrm{T}_{8}$ (Sheep manure @ $10.0 \mathrm{t} \mathrm{ha}^{-1}+$ Biofertilizers @ $5.0 \quad \mathrm{~kg} \mathrm{ha}^{-1}$ ) whereas minimum ascorbic acid (119.01, 63.25 and $53.77 \mathrm{mg} 100 \mathrm{~g}^{-1}$ ) was registered in treatment $\mathrm{T}_{5}$ (Mustard cake@1.2 $\mathrm{t} \mathrm{ha}^{-1}$ ). Increase in ascorbic acid in leaves with added biofertilizers along with vermicompost might be due to its efficacy to fix atmospheric nitrogen and enhanced carbohydrate synthesis. 
Table.1 Effect of organic manures and biofertilizers on quality parameters of spinach beet

\begin{tabular}{|c|c|c|c|c|c|c|c|c|c|}
\hline \multirow[t]{2}{*}{ Treatments } & \multicolumn{3}{|c|}{ Leaf moisture content (\%) } & \multicolumn{3}{|c|}{ Dry matter content (\%) } & \multicolumn{3}{|c|}{ Crude fibre content (\%) } \\
\hline & $I^{\text {st }}$ cutting & $2^{\text {nd }}$ cutting & $3^{\text {rd }}$ cutting & $I^{\text {st }}$ cutting & $2^{\text {nd }}$ cutting & $3^{\text {rd }}$ cutting & $I^{\text {st }}$ cutting & $2^{\text {nd }}$ cutting & $3^{\text {rd }}$ cutting \\
\hline $\mathbf{T}_{1}$ & 87.96 & 86.17 & 84.17 & 12.04 & 13.83 & 15.83 & 8.41 & 7.53 & 7.29 \\
\hline $\mathbf{T}_{2}$ & 85.75 & 83.67 & 82.27 & 14.25 & 16.33 & 17.73 & 8.67 & 7.61 & 7.34 \\
\hline$\overline{T_{3}}$ & 89.15 & 88,57 & 86.73 & 10.85 & 11.43 & 13.27 & 7.59 & 6.55 & 6.25 \\
\hline $\mathbf{T}_{4}$ & 87.97 & 86.37 & 85.63 & 12.03 & 13.63 & 14.37 & 8.51 & 7.52 & 6.41 \\
\hline $\mathbf{T}_{5}$ & 91.97 & 90.23 & 87.57 & 8.03 & 9.77 & 12.43 & 7.97 & 7.02 & 6.02 \\
\hline $\mathrm{T}_{6}$ & 84.08 & 83.53 & 81.73 & 15.92 & 16.47 & 18.27 & 9.50 & 8.86 & 7.76 \\
\hline$T_{7}$ & 87.03 & 85.60 & 84.47 & 12.97 & 14.40 & 15.53 & 9.10 & 8.56 & 7.36 \\
\hline$T_{8}$ & 86.16 & 85.30 & 83.57 & 13.84 & 14.70 & 16.43 & 9.35 & 8.68 & 7.45 \\
\hline $\mathrm{T}_{9}$ & 87.40 & 85.99 & 84.99 & 12.60 & 14.01 & 15.01 & 8.00 & 7.21 & 6.58 \\
\hline $\begin{array}{c}C . D(p \leq \\
0.05)\end{array}$ & 0.96 & 1.05 & 1.49 & 0.07 & 0.35 & 0.30 & 0.65 & 0.75 & 0.67 \\
\hline
\end{tabular}

\begin{tabular}{|c|c|c|c|c|c|c|c|c|c|}
\hline \multirow[t]{2}{*}{ Treatments } & \multicolumn{3}{|c|}{$\begin{array}{l}\text { Leaf chlorophyll content } \\
\qquad\left(\mathrm{mg} \mathrm{g} \mathrm{g}^{-1}\right)\end{array}$} & \multicolumn{3}{|c|}{ Ascorbic acid content (mg $\left.100 \mathrm{~g}^{-1}\right)$} & \multicolumn{3}{|c|}{ Leaf nitrate content $\left(\mathrm{mg} \mathrm{kg}^{-1}\right)$} \\
\hline & I $^{\text {st }}$ cutting & $2^{\text {nd }}$ cutting & $3^{\text {rd }}$ cutting & I $^{\text {st }}$ cutting & $2^{\text {nd }}$ cutting & $3^{\text {rd }}$ cutting & I $^{\text {st }}$ cutting & $2^{\text {nd }}$ cutting & $3^{\text {rd }}$ cutting \\
\hline$T_{1}$ & 1.08 & 0.28 & 0.21 & 124.41 & 66.74 & 53.43 & 811.00 & 672.33 & 608.00 \\
\hline $\mathbf{T}_{2}$ & 2.96 & 0.86 & 0.73 & 201.81 & 87.76 & 75.30 & 529.00 & 380.33 & 295.33 \\
\hline$\overline{T_{3}}$ & 2.06 & 0.55 & 0.45 & 130.39 & 78.63 & 66.91 & 588.33 & 447.66 & 355.33 \\
\hline $\mathbf{T}_{4}$ & 1.96 & 0.46 & 0.38 & 182.80 & 73.22 & 60.97 & 591.00 & 552.66 & 436.33 \\
\hline$T_{5}$ & 1.74 & 0.38 & 0.27 & 119.01 & 63.25 & 53.77 & 692.00 & 608.33 & 542.66 \\
\hline$T_{6}$ & 3.25 & 0.93 & 0.76 & 202.52 & 166.10 & 155.12 & 453.00 & 355.39 & 270.33 \\
\hline $\mathbf{T}_{7}$ & 2.96 & 0.65 & 0.54 & 197.86 & 88.58 & 73.24 & 447.33 & 348.33 & 268.33 \\
\hline $\mathrm{T}_{8}$ & 2.89 & 0.59 & 0.50 & 197.06 & 99.02 & 85.24 & 581.00 & 506.33 & 430.00 \\
\hline$T_{9}$ & 2.19 & 0.39 & 0.47 & 130.05 & 83.19 & 71.89 & 650.00 & 580.33 & 528.66 \\
\hline $\begin{array}{c}\mathrm{C.D}(\mathrm{p} \leq \\
\mathbf{0 . 0 5})\end{array}$ & 0.04 & 0.03 & 0.05 & 1.20 & 1.00 & 1.48 & 14.33 & 12.26 & 14.75 \\
\hline
\end{tabular}


Higher ascorbic acid content was reported in tomato (Meena et al., 2014) with the application of vermicompost and biofertilizers.

The maximum ascorbic acid was recorded in first cutting $\left(\mathrm{C}_{1}\right)$, followed by second cutting $\left(\mathrm{C}_{2}\right)$ and minimum was recorded in third cutting $\left(\mathrm{C}_{3}\right)$. The nutritional quality of a crop decreases because the content of nutrients especially vitamin $\mathrm{C}$ decreases with increased plant age as reported by Sorenson (1994) in lettuce.

\section{Leaf nitrate content}

The data presented in Table 1 showed that minimum leaf nitrate content $(447.33,348.33$ and $\left.268.33 \mathrm{mg} \mathrm{kg}^{-1}\right)$ was recorded in treatment $\mathrm{T}_{7}$ (Farmyard manure @ $12.0 \mathrm{t} \mathrm{ha}^{-1}$ + Biofertilizers@ @ $5.0 \mathrm{~kg} \mathrm{ha}^{-1}$ ) which was statistically at par(453.00, 355.39 and 270.33 $\mathrm{mg} \quad \mathrm{kg}^{-1}$ ) with treatment $\mathrm{T}_{6}$ (Vermicompost@3.0 t ha ${ }^{-1}+$ Biofertilizers@ $5.0 \mathrm{~kg} \mathrm{ha}{ }^{-1}$ ). Maximum nitrate content (811.00, 672.33 and $608.00 \mathrm{mg} \mathrm{kg}^{-1}$ ) was registered in treatment $\mathrm{T}_{1}$ (RFD). Similar findings were reported by Qureshi et al., (2014) and Mahmoud et al., (2009).

Regarding cutting effect on leaf nitrate, the maximum leaf nitrate was recorded in $\mathrm{C}_{1}$ which was followed by $\mathrm{C}_{2}$ whereas, minimum was recorded in $\mathrm{C}_{3}$. This might be due to nitrate reductase enzyme activity which increased with plant age and thus decreased the nitrate content. These results are in accordance with the findings of Ahmed et al., (2000) and Ruiz and Romero (2002).

\section{Benefit cost ratio}

Figure 1 revealed that the highest benefit cost ratio (3.84) was observed in treatment $\mathrm{T}_{6}$ (Vermicompost@3.0 $\mathrm{t} \mathrm{ha}{ }^{-1}+$ Biofertilizers @ $5.0 \mathrm{~kg} \mathrm{ha}^{-1}$ ) followed by (3.53) treatment
$\mathrm{T}_{2}$ (Vermicompost @ $3.0 \mathrm{t} \mathrm{ha}^{-1}$ ). The lowest benefit cost ratio (2.12) was obtained from treatment $\mathrm{T}_{5}$ (Mustard cake @ $1.2 \mathrm{t} \mathrm{ha}^{-1}$ ). Vermicompost along with biofertilizers $\left(\mathrm{T}_{6}\right)$ was focused as more profitable than any other treatment giving highest benefit cost ratio (3.84) which is due to higher leaf quality. Unique succulence, tenderness, colour and size carried higher market value than other treatments. So, it is proved that positive effect of vermicompost on quality of spinach beet can easily compete with inorganic fertilizers or other treatments as having higher benefit cost ratio. Similar findings were reported by Narolia et al., (2009) in pear millet and Sandeep (2013) in carrot.

\section{References}

Ahmed, A.H.H., Khalil, M.K. and Farrag, A.M. 2000. Nitrate accumulation, growth, yield and chemical composition of Rocket (Erucaversicaria subsp. Sativa) plant as affected by NPK fertilization, kinetin and salicylic acid, In: Proceedings of ICEHM 2000, pp: 495-508. Cairo University, Egypt.

Bharad, S.G., Snehal, D., Satpute, P. and Baviskar, M.N. 2013. Effect of organic manures and number of cuttings on growth, yield and quality of Indian spinach. The Asian Journal of Horticulture 10 (1): 60-64.

Dange, M.B., Bhosale, A.M. and Barkule, S.R. 2011. Effect of organic and inorganic fertilizers on growth, yield and quality of palak (Beta vulgaris var. bengalensis). International Journal of Plant Sciences 6 (1): 91-94.

Gairola, S., Umar, S. and Suryapani, S. 2009. Nitrate accumulation, growth and leaf quality of spinach beet as affected by NPK fertilization with special reference to potassium. Indian Journal of Science and Technology 2: 35-39.

Gomez, K.A. and A.A. Gomez 1984. 
Statistical procedures for agricultural research $(2$ ed.). John wiley and sons, New York, 680p.

Joshi, R. and Pal, V. 2010. Effect of vermicompost on growth, yield and quality of tomato (Lycopersicum esculentum L). African Journal of Basic and Applied Sciences2 (3-4): 117-123

Mahmoud, E., Abd EL- Kader, N., Robin, P., Akkal-Corfini, N. and Abd ELRahman, L. 2009. Effects of different organic and inorganic fertilizers on cucumber yield and some soil properties. World Journal of Agricultural Sciences 5 (4): 408-414.

Meena, R.K., Kumar, S., Maji, S., Kumar, D. and Kumar, M. 2014. Effect of organic manures and biofertilizers on growth, flowering, yield and quality of tomato cv. Pusa Sheetal. International Journal of Agricultural Sciences 10(1):329-332

Narkhede, S.D., Attarde, S.B. and Ingle, S.T. 2011. Study of an effect of chemical fertilizer and vermicompost on growth of Chilli pepper (Capsicum annum). Journal of Applied Sciences in Environmental Sanitation6: 327-372.

Nath, P. 1976. Origin and taxonomy. Vegetable Crops 3 (3): 246.

Qureshi, F., Wani, J.A., Bashir, U., Malik, M.A. and Mir, S.A. 2014. Response of farm yard manure and inorganic nitrogen on vegetative growth, yield and quality of leafy vegetables. $A n$ International Journal of Biology and Life Sciences 2 (3): 786-791.

Ruiz, J.M. and Romero, L. 2002. Relationship between potassium fertilization and nitrate assimilation in leaves and fruits of cucumber (Cucumis sativus) plants, Annals of Applied Biology 140: 241245.

Saadatnia, H. and Riahi, H. 2009. Cyanobacteria from paddy fields in Iran as biofertilizer in rice plants. Plant Soil and Environment 55 (5): 207-212.

Sandeep, G. 2013. Effect of organic manures on growth, root yield and quality of Carrot (Daucus carota L.), M Sc (Hort.) Thesis submitted to Dr. Y.S.R. Horticultural University, Venkataramannagudem, WestGodavari.

Singh, C.K., John, S.A. and Jaisal, D. 2014. Effect of organics on growth, yield and biochemical parameters of chilli (Capsicum annum L.). IOSR Journal of Agriculture and Veterinary Science 7 (7): 27-32.

Sorensen, J.N., Johansen, A.S., and Poulsen, N. 1994. Influence of growth conditions on the value of crisphead lettuce. Plant Foods for Human Nutrition 46: 1-11.

\section{How to cite this article:}

Asma Jabeen, Sumati Narayan, Khursheed Hussain, Shakeel Ahmed Mir and Farooq Ahmed Khan. 2018. Effect of Organic Manures and Biofertilizers on Quality of Spinach Beet (Beta vulgaris var. bengalensis). Int.J.Curr.Microbiol.App.Sci. 7(09): 1312-1317. doi: https://doi.org/10.20546/ijcmas.2018.709.156 